ISSN 0103-5150

Fisioter. Mov., Curitiba, v. 28, n. 1, p. 127-139, Jan./Mar. 2015

Licenciado sob uma Licença Creative Commons

DOI: http://dx.doi.org.10.1590/0103-5150.028.001.A013

\title{
Curricular intersections of university extension and teaching in Physical Therapy programs
}

\author{
Intersecções curriculares da extensão universitária \\ com o ensino nos cursos de Fisioterapia
}

\author{
Shamyr Sulyvan de Castro ${ }^{[a]}$, Ana Inês Sousa ${ }^{[b]}$, Miriam Cristina Pontello Barbosa Lima ${ }^{[\mathrm{c}] *}$ \\ [a] Universidade Federal do Triângulo Mineiro (UFTM), Faculdade de Fisioterapia, MG, Brazil \\ [b] Universidade Federal do Rio de Janeiro (UFRJ), Escola de Enfermagem Anna Nery, Departamento de Enfermagem de \\ Saúde Pública, Rio de Janeiro, RJ, Brazil \\ [c] Universidade Federal de Minas Gerais, Instituto de Ciências Agrárias, Belo Horizonte, MG, Brazil
}

\begin{abstract}
Introduction: University extension can be a vehicle for social change and aid in the education of university students; however, it is important to study how it is inserted in university programs so that educational actions and policies can be planned more adequately. Objectives: To study the insertion of extension activities in undergraduate physical therapy curricula in Brazilian federal universities. Method: Documentary research conducted by accessing files available on the Internet. Data were analyzed quantitatively in the form of numbers and percentages. We examined documents from 22 of the 29 federal universities that offered physical therapy programs. Results: University extension takes the form of complementary academic activities together with other options such as participating in conferences, specific training courses and working as a teaching assistant. Undergraduate physical therapy courses have a $4,000 \mathrm{~h}$ to $4,925 \mathrm{~h}$ course load, of which $0.72 \%$ to $8.9 \%$ are dedicated to extension activities. Conclusion:
\end{abstract}

\footnotetext{
* SSC: PhD, e-mail: shamyr@fisioterapia.uftm.edu.br AIS: PhD, e-mail: anaines@pr5.ufrj.br MCPBL: PhD, e-mail: miriam.pontello@gmail.com
} 
The data indicate that the insertion of extension activities in undergraduate physical therapy programs offered by Brazilian federal universities needs to be reassessed according to recommended policies and guidelines.

Keywords: Community-institutional relations. Higher education. Physical Therapy.

\section{Resumo}

Introdução: A Extensão Universitária pode ser um veículo de modificação social e de aprendizado para os acadêmicos; portanto, o estudo de sua inserção nos cursos pode contribuir para o planejamento de ações e políticas educacionais. Objetivo: Estudar a inserção de atividades de Extensão Universitária nos currículos dos cursos de graduação em Fisioterapia das universidades federais brasileiras. Método: Foi realizada uma pesquisa documental, buscando arquivos disponibilizados na internet. Os dados foram analisados quantitativamente por meio de números brutos e porcentagens. Estudou-se documentos de 22 das 29 universidades federais que oferecem cursos de Fisioterapia. Resultados: Verificou-se que as atividades de extensão são inseridas na forma de atividades acadêmicas complementares, em conjunto com atividades como participação em congressos, monitorias e cursos de aperfeiçoamento. A carga horária total dos cursos de graduação em Fisioterapia varia de 4.000h a 4.925h, e a porcentagem aproveitada para a extensão varia de 0,72\% a 8,98\%. Conclusão: Os dados mostram que a inserção da extensão nos cursos federais de Fisioterapia necessita ser repensada segundo as políticas e diretrizes preconizadas.

Palavras-chave: Relações comunidade-instituição. Educação superior. Fisioterapia.

\section{Introduction}

University extension first emerged in England in 1871. At that time, the first extension actions consisted of refresher and development courses for workers and professionals from other segments. England's pioneer experience spread throughout Europe and to the United States, which in the early 1920s added a program aimed at "meeting the specific needs of the manufacturing sector" to university extension activities. This very successful program provided technical assistance to agriculture activities (1).

In Brazil, extension emerged unassociated with social needs, based on academic proposals and unrelated to social demands (2). The term first appeared in the Brazilian law in 1931, in the Statute of Brazilian Universities (Decree-Law No. 19.851, 1931) (3), later reappearing in the Law of Directives and Bases of Education, 5.540/68. Its trajectory peaked in the 1960 s with the creation of actions such as rural training and community action centers (CRUTACs) and Project Rondon's initial operations (4). In addition, the National Student Union (UNE), on the occasion of the National Seminar on University Reform, drafted the Bahia Declaration. This manifesto documented the main resolutions agreed upon at the event, among which was the determination that universities would become open to the community through extension and community services (5).

The social context in Brazil at the end of the 1980s, marked by events such as the campaign for direct elections (Diretas Já, in 1984), the promulgation of the Federal Constitution (1988) and the implementation of direct elections (1989), promoted an approximation among university, society and citizenship. This backdrop promoted a setting of academic unrest regarding the role of university extension, and in 1987, the Brazilian Public Universities Extension Pro-Rectors Forum (FORPROEX) was created. With this forum, the concept of university extension was revisited and expanded. It was no longer just a set of activities such as courses and services made available to the community, but more directed at educational, cultural and scientific characteristics, based on the interface between universities and community (3).

According to the FORPROEX, university extension is considered "an interdisciplinary, educational, cultural, scientific and political process that promotes transformative interaction between universities and other sectors of society" (6). Extension activities must 
also walk hand in hand with teaching and research, as set forth by article 207 of the Brazilian Federal Constitution. The following guidelines were implemented for extension activities: Interdisciplinarity and interprofessionality, indissolubility of teaching research - extension, impact on student training, and impact on social transformation. Such guidelines help Brazilian higher education institutions create and implement extension actions (7).

Special emphasis must be given to the indissolubility of research, teaching and extension, the impact of extension on student training and how it can provide an innovative learning setting for students. These conditions provide students with the opportunity to integrate formal and informal learning through contact with the community, an experience that enriches their theoretical and practical professional arsenal. Furthermore, proximity with the community and other professionals gives them access to an appropriate learning environment that lends itself to multi-professional and interdisciplinary work (7). This proposal is in line with the need for health professionals to be trained within a multi-professional framework, integrated into a team, sharing knowledge from their field and coming into contact with that of others (8).

University extension in academia occurs in several different forms: 1) Programs (an articulated set of at least two projects and other extension activities, such as courses, events, services, etc., of educational, social, cultural, scientific or technological nature, developed as an ongoing process which integrates teaching and research); 2) Projects (educational, social, cultural, scientific or technological actions integrating teaching and research, encompassing courses, events and services, affiliated or not affiliated to a program); 3) Courses (educational actions of theoretical and/ or practical nature, on-campus or online, planned and organized systematically and with an 8-hour minimum course load, defined assessment criteria and certification, which abide by the precepts of extension); 4) Events (public presentations and/ or exhibits open to the general or a specific public, consisting of a cultural, artistic, sporting, scientific/ academic or technology product that was developed, conserved or recognized by the university); and 5) Service provision (the study and solution of problems by professional or social means, such as the development of new educational and research approaches and knowledge and/or technology transfer to society, conducted by professors/technicians together with students committed to the University's political project) (9). The FORPROEX provides another, more summarized definition of service provision, namely, "work offered by Higher Education Institutions or outsourced providers (community, companies, public bodies, etc.). Furthermore, its process and product must be intangible and inseparable, not resulting in the acquisition of goods" (10).

Some programs in the field of health, including physical therapy (15), have made efforts to change their curricula in order to satisfy broader criteria for teaching, research and extension activities $(11,12$, $13,14)$. It is worth clarifying that university extension can help make curricula more flexible, a process that is not in line with the current predominant pedagogical concept in Brazil, which is based on a fixed curricular structure. Thus, extension activities expand the concept of a curriculum, defined as a set of academic knowledge experiences made available to students $(3,16)$.

Successful extension experiences in the field of physical therapy have been reported by the literature in several areas, such as in work with older adults (17, 18), pregnant women (19), health education (20), and home care (21). Programs in the field of health are a fertile ground for extension activities and a place for improving professional training $(22,23)$. As a discipline within the health field, physical therapy also presents this possibility, and several programs have structured their curricula around teaching, research and extension $(7,15)$. This should be the overall trend, as article 8 of the National Curricular Guidelines (DCNs) established by the Brazilian Ministry of Education (MEC) states that extension programs must be implemented in physical therapy courses as mechanisms for making use of knowledge acquired by students (25).

In this context, the study of extension activities and how they are included in undergraduate physical therapy curricula offered by Brazilian federal universities can contribute by revealing the academic interface between physical therapy teaching and university extension. By establishing this panorama, such studies can help guide educational measures, policies and programs that seek to adjust physical therapy programs to the MEC standards. Moreover, physical therapy is by nature a discipline that is strongly characterized by specialized rehabilitation processes and that is closely associated with healthcare technology and equipment. 
However, it is also an occupation in which there is great proximity and intense relationships with patients or persons being cared for. Such characteristics make it easier to establish an environment that favors university extension, as it brings together two important actors in this scenario, students and the community.

Extension activities can be a vehicle for changing the profile of physical therapists, in that they require that these professionals put academic knowledge in practice in an environment where they are in close contact with the social reality of patients. It also provides a work or interaction situation marked by technological simplicity, requiring that their interventions be creative and that students adjust to the social context of patients (26). In light of the above, the objective of this study was to examine the insertion of university extension activities in the curricula of undergraduate physical therapy programs offered by Brazilian federal universities.

\section{Method}

This was a documentary study that analyzed the curricular structure of undergraduate physical therapy programs offered by Brazilian universities currently in activity throughout the country and whose classification is available on the Ministry of
Education's e-MEC platform (accessed by the internet site emec.mec.gov.br), the search was conducted between March and April 2013.

We examined all records of student academic extension activities (pedagogical projects, rules of procedure, statutes and others) available online relative to physical therapy programs offered by federal universities. Data were analyzed quantitatively in the form of numbers and percentages.

At the time of the study, there were 29 federal universities with physical therapy programs distributed throughout Brazil, as illustrated in Table 1.

\section{Results}

Of the 29 federal institutions that offered physical therapy programs and that were classified by the MEC, seven (UFES, UFMG, UFJF, UFBA, UFG, IFRJ and UFRJ) did not present documentation proving or standardizing extension activities on the Internet. Table 2 lists the 22 institutions that did have such documents available and show how extension activities were included in their curricula.

Figure 1 below illustrates the percentage distribution of hours of recommended complementary activities compared to the total course load for each of the investigated programs.

Table 1 - Distribution of Brazilian federal higher education institutions with undergraduate physical therapy programs by state, 2013

(To be continued)

\begin{tabular}{lcc}
\hline Institution & Acronym & State \\
\hline Universidade de Brasília & UNB & Federal District \\
Universidade Federal de Sergipe & UFS & Sergipe \\
Universidade Federal do Amazonas & UFAM & Amazonas \\
Universidade Federal do Piauí & UFPI & Piauí \\
Universidade Federal de São Carlos & UFSCAR & São Paulo \\
Universidade Federal de Uberlândia & UFU & Minas Gerais \\
Universidade Federal do Pará & UFPA & Pará \\
Universidade Federal do Rio Grande do Norte & UFRN & Rio Grande do Norte \\
Universidade Federal do Paraná & UFPR & Paraná \\
Universidade Federal do Espírito Santo & UFES & Espírito Santo \\
Universidade Federal de Minas Gerais & UFMG & Minas Gerais \\
Universidade Federal de Juiz de Fora & UFJF & Minas Gerais
\end{tabular}


Table 1 - Distribution of Brazilian federal higher education institutions with undergraduate physical therapy programs by state, 2013

(Conclusion)

\begin{tabular}{lcc}
\hline Institution & Acronym & State \\
\hline Universidade Federal da Paraíba & UFPB & Paraíba \\
Universidade Federal de Pernambuco & UFPE & Pernambuco \\
Universidade Federal do Rio Grande do Sul & UFRGS & Rio Grande do Sul \\
Universidade Federal de Santa Maria & UFSM & Rio Grande do Sul \\
Universidade Federal do Ceará & UFC & Ceará \\
Universidade Federal de Goiás & UFG & Goiás \\
Universidade Federal de Santa Catarina & UFSC & Santa Catarina \\
Universidade Federal do Rio de Janeiro & UFRJ & Rio de Janeiro \\
Universidade Federal de São Paulo & UNIFESP & São Paulo \\
Universidade Federal de Alfenas & UNIFAL-MG & Minas Gerais \\
Universidade Federal dos Vales do Jequitinhonha e Mucuri & UFVJM & Minas Gerais \\
Universidade Federal do Triângulo Mineiro & UFTM & Minas Gerais \\
Universidade Federal do Mato Grosso do Sul & UFMS & Mato Grosso do Sul \\
Universidade Federal de Ciências da Saúde de Porto Alegre & UFCSPA & Rio Grande do Sul \\
Instituto Federal do Rio de Janeiro & IFRJ & Rio de Janeiro \\
Universidade Federal do Pampa & UNIPAMPA & Rio Grande do Sul \\
\hline
\end{tabular}

Source: e-MEC (emec.mec.gov.br).

Table 2 - Distribution of federal institutions that offer physical therapy programs, type of documentation used, and how extension activities are inserted in the undergraduate curriculum

(To be continued)

\begin{tabular}{|c|c|c|c|c|}
\hline Institution & $\begin{array}{c}\text { Available } \\
\text { documentation }\end{array}$ & $\begin{array}{l}\text { How extension is } \\
\text { inserted in curriculum }\end{array}$ & Form of insertion & $\begin{array}{l}\text { Program's total } \\
\text { course load }^{\mathrm{a}}\end{array}$ \\
\hline UFAM (27) & $\begin{array}{l}\text { Resolution for } \\
\text { undergraduate programs }\end{array}$ & $\begin{array}{l}\text { Complementary } \\
\text { activities (CA) }\end{array}$ & $\begin{array}{l}200 \text { hours (extension, teaching } \\
\text { or research) }\end{array}$ & 4,410h \\
\hline UFC (28) & $\begin{array}{l}\text { Pedagogical and political } \\
\text { project }\end{array}$ & CA & $\begin{array}{l}140 \text { hours (extension, teaching } \\
\text { or research) }\end{array}$ & $4,496 \mathrm{~h}$ \\
\hline UFCSPA (29) & $\begin{array}{l}\text { Standards for } \\
\text { undergraduate programs }\end{array}$ & CA & 300 points $^{b}$ & $4,925 \mathrm{~h}$ \\
\hline UFMS (30) & Pedagogical project & CA & $\begin{array}{l}136 \text { hours (academic, scientific, } \\
\text { cultural and social activities in } \\
\text { the health field) }\end{array}$ & $4,500 \mathrm{~h}$ \\
\hline UFPA (32) & $\begin{array}{l}\text { Program's pedagogical } \\
\text { project }\end{array}$ & CA & $\begin{array}{l}270 \text { hours (research, extension, } \\
\text { teaching assistance, or others) }\end{array}$ & $4,650 \mathrm{~h}$ \\
\hline UFPB (32) & $\begin{array}{l}\text { Pedagogical and political } \\
\text { project }\end{array}$ & CA & $\begin{array}{l}345 \text { hours (extension, teaching, } \\
\text { research, or others) }\end{array}$ & $4,500 \mathrm{~h}$ \\
\hline UFPE (33) & Pedagogical project & CA & $\begin{array}{l}30 \text { hours of elective courses } \\
\text { or complementary activities } \\
\text { (extension, teaching or research) }\end{array}$ & $4,140 \mathrm{~h}$ \\
\hline UFPI (34) & Pedagogical project & $\mathrm{CA}$ & 120 hours $^{c}$ & $4,590 \mathrm{~h}$ \\
\hline UFPR (35) & $\begin{array}{c}\text { Resolution for } \\
\text { undergraduate program }\end{array}$ & $\begin{array}{c}\text { Complementary training } \\
\text { activities }\end{array}$ & $\begin{array}{l}359 \text { hours unspecified in } \\
\text { documentation }\end{array}$ & $4,000 \mathrm{~h}$ \\
\hline UFRGS (36) & $\begin{array}{l}\text { Resolution for } \\
\text { undergraduate programs }\end{array}$ & CA & 15 complementary credits ${ }^{\mathrm{d}, \mathrm{e}}$ & $4,530 \mathrm{~h}$ \\
\hline
\end{tabular}


de Castro SS, Sousa Al, Lima MCPB.

Table 2 - Distribution of federal institutions that offer physical therapy programs, type of documentation used, and how extension activities are inserted in the undergraduate curriculum

(Conclusion)

\begin{tabular}{|c|c|c|c|c|}
\hline Institution & $\begin{array}{c}\text { Available } \\
\text { documentation }\end{array}$ & $\begin{array}{l}\text { How extension is } \\
\text { inserted in curriculum }\end{array}$ & Form of insertion & $\begin{array}{l}\text { Program's total } \\
\text { course load }^{\text {a }} \\
\end{array}$ \\
\hline UFRN (37) & Pedagogical project & $\begin{array}{l}\text { Certified complementary } \\
\text { activities }\end{array}$ & $\begin{array}{l}90 \text { hours (teaching, research, } \\
\text { extension, student body } \\
\text { representation and participation } \\
\text { in events) }\end{array}$ & $4,260 \mathrm{~h}$ \\
\hline UFS (38) & Course syllabus & CA & $\begin{array}{l}210 \text { hours (extension, research, } \\
\text { teaching or others) }\end{array}$ & $4,515 \mathrm{~h}$ \\
\hline UFSC (39) & $\begin{array}{l}\text { Pedagogical and political } \\
\text { project }\end{array}$ & CA & 144 hours $^{\dagger}$ & $4,005 \mathrm{~h}$ \\
\hline UFSCAR (40) & $\begin{array}{c}\text { Pedagogical and political } \\
\text { project }\end{array}$ & CA & Not requiredg & $4,020 \mathrm{~h}$ \\
\hline UFSM (41) & $\begin{array}{c}\text { Pedagogical and political } \\
\text { project }\end{array}$ & $\begin{array}{c}\text { Complementary } \\
\text { undergraduate programs }\end{array}$ & $\begin{array}{l}240 \text { hours (42) (extension, } \\
\text { research, teaching or others) }\end{array}$ & $4,590 \mathrm{~h}$ \\
\hline UFTM (43) & Rules of procedure & $\begin{array}{l}\text { Academic-scientific- } \\
\text { cultural activities }\end{array}$ & $\begin{array}{l}230 \text { hours (extension, research, } \\
\text { teaching, professional } \\
\text { development or others) }\end{array}$ & $4,220 \mathrm{~h}$ \\
\hline UFU (44) & Pedagogical project & $\begin{array}{l}\text { Complementary } \\
\text { academic activities }\end{array}$ & $\begin{array}{l}180 \text { hours (extension, research, } \\
\text { teaching, professional } \\
\text { development or others) }\end{array}$ & $4,445 h$ \\
\hline UFVJM (45) & Pedagogical project & CA & $\begin{array}{l}210 \text { hours (extension, research, } \\
\text { professional development and } \\
\text { cultural enrichment, teaching } \\
\text { initiation, or others) }\end{array}$ & $4,395 \mathrm{~h}$ \\
\hline UnB (46) & Pedagogical project & $\mathrm{CA}$ & 246 hours $^{\text {h }}$ & $4,000 \mathrm{~h}$ \\
\hline UNIFAL (47) & $\begin{array}{l}\text { Pedagogical and political } \\
\text { project }\end{array}$ & Training activities & $\begin{array}{l}214 \text { hours (extension, research, } \\
\text { teaching, professional } \\
\text { development or others) }\end{array}$ & $4,205 \mathrm{~h}$ \\
\hline UNIFESP (48) & Program regulation & $\begin{array}{l}\text { Complementary } \\
\text { undergraduate activities }\end{array}$ & $\begin{array}{l}240 \text { hours (extension, research, } \\
\text { teaching, professional } \\
\text { development or others) }\end{array}$ & $5,240 \mathrm{~h}$ \\
\hline $\begin{array}{l}\text { UNIPAMPA } \\
\text { (49) }\end{array}$ & Pedagogical project & $\begin{array}{c}\text { Complementary } \\
\text { undergraduate activities }\end{array}$ & $\begin{array}{l}200 \text { hours (extension, research, } \\
\text { teaching, professional } \\
\text { development or others) }\end{array}$ & $4,590 \mathrm{~h}$ \\
\hline
\end{tabular}

Notes: a Information available at: http://emec.mec.gov.br/.

${ }^{\mathrm{b}}$ Further details on what comprises extension, teaching and research points and hours are available in the material listed in the reference section. One example, however, is that by participating in an extension project students earn 20 points per semester, the same value attributed to the publishing of an article in a Brazilian journal.

"There was no mention of the name "extension activities" as complementary activities in the program's pedagogical project. However, the definition provided for complementary activities was "extracurricular activities, such as courses taken in related fields of knowledge that provide the recognition of skills and competences and that place students in contact with their social, economic and cultural reality and even with research and teaching initiation programs. Mainly, such activities provide an opportunity for the interrelation of theory and practice in the process of learning and personal development" (35).

${ }^{d}$ Complementary credits must be completed within at least two different groups of activity (extension, research, teaching) and different credits are attributed to activities conducted in and outside UFRGS. For example, one complementary credit corresponds to 60 hours of participation in an extension project or to publishing a scientific article.

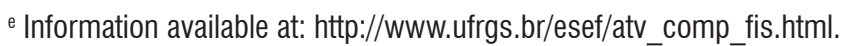

'Students must have participated in activities in at least three of the following groups: I - Teaching and research initiation activities; II Conferences, seminars, conventions, and other assisted activities; III - Publishing and presenting work at scientific events; IV - Complementary professional experience; $\mathrm{V}$ - Complementary training courses. The table of points does not mention extension activities by name. ${ }^{9}$ Complementary activities are not part of the required credits. However, if carried out, they count as credits towards the program's completion.

${ }^{\mathrm{h}}$ There was no description on the nature of complementary activities in the program's pedagogical project. 


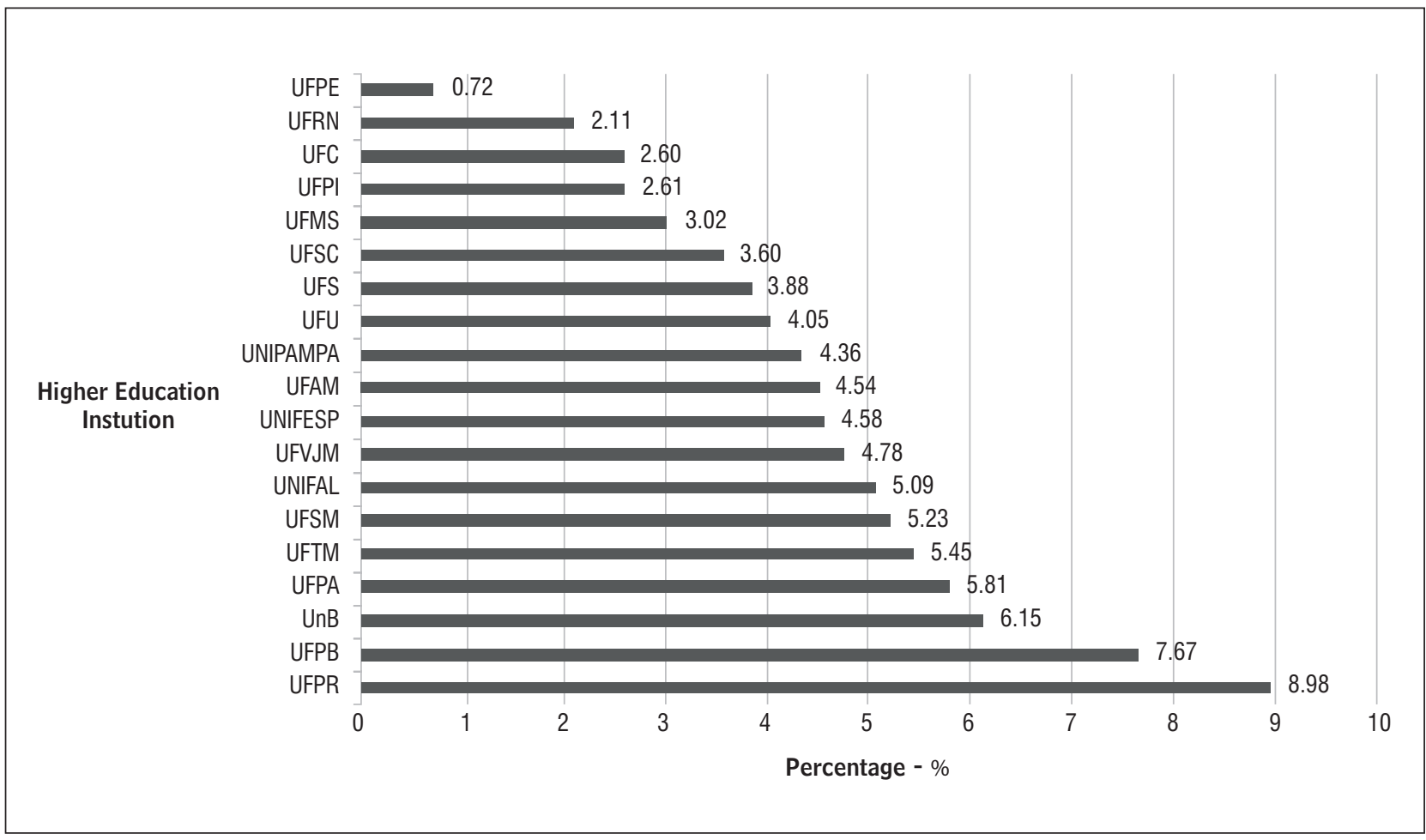

Figure 1 - Percentage distribution of recommended complementary activities in hours compared to the total course load in hours, including university extension activities, by institution

Note: Not included in Figure 1: UFSCar (no documentation was found on required academic activities); UFCSPA and UFRGS (the number of hours granted varied according to each activity).

\section{Discussion}

The vast majority of physical therapy programs offered by the studied institutions provided students with extension experiences and opportunities, as established by curricular guidelines (DCNs) (25). However, they were offered as complementary activities, which students can choose whether or not to take. According to resolution no. 492/2001 of the Brazilian National Education Council/Higher Education Chamber (CNE/CES), the intention of complementary activities is to promote a relationship between students and their social, economic and cultural reality, as well as with research and teaching initiation. They take up a flexible number of hours per week and students can decide how much time to dedicate to such activities during the semester or school year (50).

It is worth mentioning that the information gathered in this study does not concern hours of required curricular internships. These are part of the main curriculum and occupy $20 \%$ of the program's total course load, in accordance with DCN guidelines regarding supervised professional practice (51). We bring attention to the fact that extracurricular internships that do not provide proper supervision or are not affiliated to a teaching institution represent a blatant violation of the legal framework established by the Brazilian Federal Council of Physical Therapy and Occupational Therapy (COFFITO) (53).

The DCNs for physical therapy programs recommend the following complementary activities: teaching assistance jobs and internships, scientific initiation programs, extension programs, complementary studies, and courses conducted in related fields (51). These guidelines are complemented by Resolution 4/2009 of the National Education Council (CNE) (53), which establishes a minimum total course load of 4,000 hours (60-minute hours) (53). According to the data gathered in this study, all institutions abided by CNE recommendations and many went beyond the minimum hour requirement, following COFFITO guidelines that suggest a total course load of at least 4,500 hours (information available at www.coffito.org.br).

Figure 1 demonstrates that the percentage of hours of complementary activities with respect to 
total course load varied considerably. We found institutions that did not standardize their required academic or extension activities and one that recommended that they occupy nearly $9 \%$ of total course load (25). The latter came very close to the $10 \%$ target established by the Brazilian National Education Plan (PNE) (54) for extension activities in undergraduate programs, sanctioned in June 2014. The autonomy of universities in determining internship and complementary activity workload has had a negative impact on extension activities. With so much emphasis on internships, extension activities end up representing a very small portion of the program's course load. This situation can lead students to experience few hours of extension activities during their undergraduate studies, as complementary activities represent a low percentage of their total workload.

Furthermore, complementary activities encompass a great variety of options, such as participating in events inside and outside the university (academic weeks, conferences, seminars, talks, conventions, cultural activities, taking extension and/or academic and professional development courses), scientific initiation and teaching assistant jobs (information available at portal.mec.gov.br). However, academic activities cannot be limited to the possibilities presented by the MEC.

The University of Santa Catarina (UFSC), for instance, presents the following complementary activities: taking on teaching assistant jobs and tutoring online courses; participating in extension activities, institutional research and projects; participating in extension projects or activities; participating in scientific events (conferences, seminars, conventions or other events of short or long duration); attending dissertation or thesis defenses; attending endof-course paper presentations; conducting technical visits; publishing scientific articles; presenting academic work at scientific events; completing extracurricular internships; participating in social projects and being active in a student representative body (information available at http://fisio.ufsc. br/regulamento-de-atividades-complementares/).

In addition to other activities already mentioned, another higher education institution, UFRN, offers participation in research groups; research initiation scholarships; authoring and co-authoring book chapters; being awarded at scientific events, and acting as a representative in university bodies (information available at http://fisio.ufsc.br/ regulamento-de-atividades-complementares/). Thus, students can complete their academic course load in areas not exclusively related to extension. If a student publishes an article, works as a teaching assistant, and presents a paper in a scientific event, he or she can complete the total hours of required complementary activities without having participated in any continuous extension activity, such as an extension project or program in association with their course work. Therefore, such flexibility and the great variety of possible academic activities can be a limiting factor to extension experiences in undergraduate programs, in that students can seek out and prioritize activities that are not related to extension in order to complete their required course load of complementary academic activities.

An attempt to reduce the impact of such factors in the scope of complementary activities can be verified in the UFSC's political and pedagogical project for their physical therapy program. The project divides complementary activities into five groups (I - Teaching and research initiation activities; II Conferences, seminars, conventions and other assisted activities; III - Publishing and presenting academic work at scientific events; IV - Complementary professional experience; $\mathrm{V}$ - Complementary training courses) and students are required to register for at least three of them (39). This model is an interesting solution, as it increases the variety of academic activities carried out by students and guarantees that they do not complete their required course load only within two groups. However, even this proposal does not ensure participation in extension activities, it only increases such chances.

Another point we would like to highlight is that $10 \%$ of the total required course load for completing physical therapy programs is assigned to extension activities, as established by the PNE and Law 13.005, 2014 (54). Clearly, this requirement was not met by the universities in the present study.

Our purpose with this research is to make extension activities mandatory for all undergraduate students, with a minimum course load to be established according to the program's total course load. A second alternative proposal would be to include required practical courses that work extension activities into a program's curricular structure. Some institutions have adopted this measure, offering specific extension classes, such as "Cultural and Extension Activities", an elective discipline offered by the 
University of São Paulo (55); "Extension Practice”, a required class in UFSC's Oceanography program (information available at http://oceanografia.ufsc. br/curriculo-do-curso/ementas-das-disciplinas/); "Extension in Geography", required by UnB's department of Geography; "Community Extension I", an extracurricular class in Unicamp's undergraduate program (available at http://www.dac.unicamp. $\mathrm{br} /$ sistemas/horarios/grad/G1S0/EX001.htm), and "Fundamentals and Methodology of University Extension", an optional part of the Pharmacy program offered by UNESP-Araraquara (available at www2. fcfar.unesp.br). Through such measures, extension activities would become a guaranteed part of students' academic life and PNE guidelines would be respected.

The proposals presented above are based on the principle of the indissolubility of research, extension and teaching, as established in the Brazilian constitution of 1988 (56). This principle would guarantee the integration of the knowledge held by the community and that of science, as well as interrelate research, teaching and extension (57). Thus, it is expected that every undergraduate student participate in learning, research and extension activities throughout their studies. However, it is well known that research occupies a preponderant role compared to other activities, considering that it is often the framework for extension and teaching. Therefore, professors teach and students learn by conducting research; and services are also provided based on research activities (58). This trend has been fought by the FORPROEX, which has directed its efforts to reinforcing the need for curricular flexibility, offering the bases and directives to strengthen university in the Brazilian system of higher education (3). The possibility of students completing their program without participating in extension activities violates these principles. Therefore, by making extension activities a required part of undergraduate programs together with research and teaching, the constitution will be upheld.

However, we must emphasize that making extension activities mandatory through classes or activities connected to extension projects or programs requires institutional planning and restructuring. An institution that proposes to assign $10 \%$ of its course load to extension activities will create a great demand for such activities and it will have to guarantee sufficient places for all students. Implementing a class on extension also requires careful planning and precautions to avoid that it becomes an isolated part of the program and so that students can get the most out of it. As discussed above, in order for any of the proposals presented here to be implemented successfully, the institutions must plan and prepare it appropriately. The correct planning and execution of proposals will help institutionalize such changes and in this way, they will become an integral part of the curricular structure.

Research activities are already a required part of physical therapy courses, as expressed by article 12 of the DCNs, which establishes that "In order for students to earn a bachelor's degree in physical therapy, they must carry out a research study under the guidance of an advisor" (25). Therefore, research and teaching are already contemplated by force. However, this is not the case of extension activities, for students can earn their degrees without ever participating in one. This situation reinforces the need for extension activities to a required part of undergraduate physical therapy programs, be they in the form of complementary activities or even in the form of a class included in the program's curriculum, or some other strategy to this end. Moreover, in order to ensure a more enriching experience for students, it is important that extension actions be continuous and not relegated to one-time activities or to participating in courses, events or service provision.

We emphasize that this is a documentary study and its results were based on material available online. This was its greatest limitation, as there might be other more recent documents with different content that are not digitally available. Furthermore, this research could have included data from community and private higher education institutions so as to establish a more comprehensive panorama of the insertion of extension activities in Brazilian undergraduate physical therapy programs. However, up to the present, there are no publications that approach this subject specifically. Furthermore, the investigation process adopted here can help guide other programs to revisit and debate the role and insertion of university extension in their curricular structures.

\section{Conclusion}

The insertion of university extension in undergraduate physical therapy programs takes the form of complementary activities, together with other options such as participating in conferences, working as a teaching assistant or taking development courses. 
As the workload of these activities is usually reduced, it would be interesting for students to participate in programs and projects. These have longer duration and offer more transformative opportunities due to their continuous, deeper and involving nature, thus helping to change the profile of the physical therapist. We highlight that in terms of percentages, none of the studied higher education institutions reached $10 \%$ of total course load assigned to extension activities, as recommended by the PNE.

We propose that a specific and required course load reserved specifically for extension activities be included in program curricula in the form of classes or supplementary curricular requisites (RCS). Students would register for such classes or RCS and complete the required course load by participating in extension programs and projects, such as will be done at the Federal University of Rio de Janeiro starting January 2014.

Universities can also come up with other proposals to guarantee the presence of extension activities in students' curriculum and thus abide by the principle of indissolubility of teaching, research and extension in higher education, presented by the Brazilian constitution and proposed by the DCNs for physical therapy programs and by the PNE. However, in order for any proposal to be implemented, proper planning is required, one that allows for the curriculum to be adjusted and higher education institutions to be restructured in order to guarantee the necessary conditions for executing and institutionalizing such measures.

\section{References}

1. Paula JA. A Extensão Universitária e a sociedade contemporânea. Boletim UFMG. 201030 ago [cited 2015 Feb 10];36(1708). Available from: https://www.ufmg. br/boletim/bol1708/2.shtml

2. Cruz RS, dos Santos PDR, Souza AMSA, Lima JC, Santos MCS, de Jesus NA, et al. Extensão Universitária: um caso de ação voltada ao desenvolvimento social em saúde. CGHS. 2013;1(16):127-34.

3. Fórum de Pró-Reitores de Extensão das Universidades Públicas Brasileiras. Indissociabilidade ensino-pesquisa-extensão e a flexibilização curricular: uma visão da extensão. Porto Alegre: UFRGS; Brasília: MEC/ SESu; 2006.
4. Arroyo DMP, Rocha MSPML. Meta-avaliação de uma Extensão Universitária: Estudo de caso. Avaliação (Campinas). 2010;15(2):131-57.

5. Mendonça AWPC. A universidade no Brasil. Rev Bras Educ. 2000;(14):131-94.

6. Fórum de Pró-Reitores de Extensão das Universidades Públicas Brasileiras. Política nacional de Extensão Universitária. Manaus: FORPROEX; 2012 [cited 2015 Feb 10]. Available from: http://www.renex.org. br/documentos/2012-07-13-Politica-Nacional-deExtensao.pdf

7. Marães VRFS, Martins EF, Cipriano Junior G, Acevedo AC, Pinho DLM. Projeto pedagógico do curso de Fisioterapia da Universidade de Brasília. Fisioter Mov. 2010;23(2):311-21.

8. Ferreira RC, Varga CRR, Silva RF. Trabalho em equipe multiprofissional: a perspectiva dos residentes médicos em saúde da família. Ciênc Saúde Coletiva. 2009; 14(Sup. 1):1421-8.

9. Universidade Federal de Minas Gerais - UFMG. Pró-Reitoria de Extensão. Manual do SIEX. Belo Horizonte: UFMG; 2012 [cited 2015 Feb 10]. Available from: https://www2.ufmg.br/proex/content/download/329/2021/version/1/file/Manual+do+Siex.pdf

10. Fórum de Pró-Reitores de Extensão das Universidades Públicas Brasileiras. Extensão universitária: organização e sistematização. Belo Horizonte: Coopmed; 2007.

11. Lima VV, Komatsu RS, Padilha RQ. Desafios ao desenvolvimento de um currículo inovador: a experiência da Faculdade de Medicina de Marília. Interface (Botucatu). 2003;7(12):175-84.

12. Renovato RD, Bagnato MHS, Lourdes Missio L, Bassinello GAH. As identidades dos enfermeiros em cenários de mudanças curriculares no ensino da enfermagem. Trab Educ Saúde. 2009;7(2):231-48.

13. Toassi RFC, Davoglio RS, Lemos VMA. Integração ensino-serviço-comunidade: o estágio na atenção básica da graduação em Odontologia. Educ Rev. 2012; 28(4):223-42.

14. Trenche MCB, Barzaghi L, Pupo AC. Mudança curricular: construção de um novo projeto pedagógico de formação na área da Fonoaudiologia. Interface (Botucatu). 2008;12(27):697-711. 
15. Signorelli MC, Israel VL, Corrêa CL, Motter AA, Takeda SYM, Gomes ARS. Um projeto político-pedagógico de graduação em Fisioterapia pautado em três eixos curriculares. Fisioter Mov. 2010;23(2):331-40.

16. Santos AP, Lima AA, Carrillo MRGG, Bortolini NGS. Extensão: uma ferramenta para a flexibilização curricular e a construção social do conhecimento. Avaliação (Campinas). 2005;10(3):93-104.

17. Berlezi EM, Eickhoff HM, de Oliveira KR, Dallepiane LB, Perlini NMOG, Mafalda A, et al. Programa de atenção ao idoso: relato de um modelo assistencial. Texto Contexto - Enferm. 2011;20(2):368-70.

18. Oliveira TVC, Santos Júnior L, Fontes PA, de Almeida RD, Cândido EAF. Fisioterapia no idoso da comunidade: relação transformadora entre universidade e sociedade através da extensão, articulando ensino e pesquisa. Scire Salut. 2011;1(2):5-14.

19. Strassburger SZ, Dreher DZ. A fisioterapia na atenção a gestantes e familiares: relato de um grupo de extenção universitária. Sci Med. 2006;16(1):23-6.

20. Arrais R, Hildegardes M, Pessoa IMBS, Coelho CC. Educando para a saúde: uma atuação da fisioterapia na extensão universitária. Vivências. 2009;5(8): 107-11.

21. Torres CKD, Estrela JFM, Ribeiro KSQS. Contribuição da educação popular no atendimento fisioterapêutico domiciliar. Ciênc Saúde Coletiva. 2009;14(5):1877-9.

22. Brêtas J, Pereira S. Projeto de Extensão Universitária: um espaço para formação profissional e promoção da saúde. Trab Educ Saúde. 2007;5(2):317-27.

23. Tavares DMDS, Simões ALA, Dal Poggetto MT, da Silva SR. The interface of teaching, research and extension in undergraduate courses in health. Rev Latino-Am Enfermagem. 2007;15(6):1080-5.

24. Ribeiro KSQS. A experiência na extensão popular e a formação acadêmica em fisioterapia. Cad CEDES. 2009;29(79):335-46.

25. Brasil. Ministério da Educação. Resolução CNE/CES n. 4, de 19 de fevereiro de 2002. Institui Diretrizes Curriculares Nacionais do Curso de Graduação em Fisioterapia. Brasília; 2002 [cited 2015 Feb 10]. Available from: http://portal.mec.gov.br/cne/arquivos/ pdf/CES042002.pdf
26. Ribeiro KSQS. Fisioterapia na comunidade: a possibilidade de mudanças na formação acadêmica a partir de um projeto de extensão. In: Melo Neto JF, editor. Extensão Universitária: diálogos populares [internet]. 2002 [cited 2015 Feb 10]. Available from: http://www.prac. ufpb.br/copac/extelar/producao_academica/livros/ pa_l_2002_extensao_dialogos_populares.pdf

27. Universidade Federal do Amazonas - UFAM. Conselho de Ensino, Pesquisas e Extensão. Câmara de Ensino de Graduação. Resolução n. 018/2007, de 1ํㅡㄴ agosto de 2007. Regulamenta as Atividades Complementares dos Cursos de Graduação da Universidade Federal do Amazonas. Manaus; 2007 [cited 2015 Feb 10]. Available from: http://proeg.ufam.edu.br/ attachments/083_Resolu\%C3\%A7\%C3\%A30\%20 N\%C2\%BA\%20018_2007_CONSEPE_CEG.pdf

28. Universidade Federal do Ceará - UFC. Projeto Político Pedagógico do Curso de Fisioterapia. Fortaleza; 2009 [cited 2015 Feb 10]. Available from: http://www.fisioterapia.ufc.br/images/stories/arquivos/noticiaseeventos/projeto_pedagogico_fisioterapia.pdf.

29. Universidade Federal de Ciências da Saúde de Porto Alegre - UFCSPA. Normas para as atividades complementares nos cursos de graduação da UFCSPA. Porto Alegre; 2012 [cited 2015 Feb 10]. Available from: http://www.ufcspa.edu.br/ufcspa/normasedocs/ docs/010b.pdf

30. Universidade Federal do Mato Grosso do Sul - UFMS. Boletim de Serviço. Campo Grande; 2011. Available from: ftp://ftp.editora.ufms.br/pub/bs2011/Setembro/BS 5132.pdf.

31. Universidade Federal do Pará - UFPA. Instituto de Ciências da Saúde. Projeto Pedagógico para Criação do Curso de Fisioterapia. Belém; [s. d.]. Available from: http://www.ffto.ufpa.br/arquivos/PP_Fisioterapia.pdf.

32. Universidade Federal da Paraíba - UFPB. Conselho Superior de Ensino, Pesquisa e Extensão. Resolução 12/2005, de 3 de junho de 2005. Aprova o Projeto Político-Pedagógico do Curso de Graduação em Fisioterapia, do Centro de Ciências da Saúde, Campus I, desta Universidade, revoga a Resolução UFPB/ CONSEPE n. 21/84 e dá outras providências. João Pessoa; 2005 [cited 2015 Feb 10]. Available from: http://www.ufpb.br/sods/consepe/resolu/2005/ Rsep12_2005.htm 
33. Universidade Federal de Pernambuco - UFPE. Projeto Pedagógico do Curso de Fisioterapia. Recife; 2007 [cited 2015 Feb 10]. Available from: http://www.ufpe. br/ccs/images/Documentos/Fisioterapia/projeto_ pedagogico_fisioterapia.pdf

34. Universidade Federal do Piauí - UFPI. Projeto Político Pedagógico do Curso de Bacharelado em Fisioterapia. Teresina; 2006 [cited 2015 Feb 10]. Available at: http://www.ufpi.br/subsiteFiles/cc/arquivos/files/ fisioterapia_cmrv.pdf

35. Universidade Federal do Paraná - UFPR. Resolução 11/2010. Curitiba; 2010. Available at: http://www. litoral.ufpr.br/sites/default/files/Resolucao1110CEPEFisioterapia.PDF

36. Universidade Federal do Rio Grande do Sul - UFRGS. Conselho de Ensino, Pesquisa e Extensão. Resolução 24/2006, de 3 de maio de 2006. Regulamenta as atividades complementares na graduação. Porto Alegre; 2006 [cited 2015 Feb 10]. Available from: http://www.ufrgs.br/cepe/legislacao/resolucaono-24-2006-de-03-05-2006

37. Universidade Federal do Rio Grande do Norte - UFRN. Faculdade de Ciências da Saúde do Trairi. Projeto pedagógico do curso de Fisioterapia em Santa Cruz/RN revisão e adequação - núcleo docente estruturante. Santa Cruz; 2011 [cited 2015 Feb 10]. Available from: http://www.sistemas.ufrn.br/shared/verArquivo?i $\mathrm{d}$ Arquivo $=1649543 \& \mathrm{key}=75 \mathrm{dd} 36 \mathrm{a} 0227 \mathrm{aae} 8 \mathrm{e} 95 \mathrm{bd}$ 6c879774ea39

38. Universidade Federal de Sergipe - UFS. Atividades Complementares. Aracaju; s. d.]. Available from: http://www.daa.ufs.br/textos/guia/Ativ_Complementar.htm

39. Universidade Federal de Santa Catarina - UFSC. Centro de Ciências Biológicas e da Saúde. Projeto Político Pedagógico do Curso de Bacharelado em Fisioterapia - Campus Araranguá. Florianópolis; 2010 [cited 2015 Feb 10]. Available from: http://fisio.ufsc.br/ files/2012/04/PPP-DE-FISIOTERAPIA-versão-IIc.pdf

40. Universidade Federal de São Carlos - UFSCar. Centro de Ciências Biológicas e da Saúde. Projeto Político Pedagógico do Curso de Fisioterapia: para atendimento às determinações legais de 4.000h. São Carlos; 2013 [cited 2015 Feb 10]. Available from: http:// www.dfisio.ufscar.br/projeto-politico-pedagogico-docurso-de-graduacao-em-fisioterapia-da-ufscar
41. Universidade Federal de Santa Maria - UFSM. Projeto Político Pedagógico. Santa Maria; [s. d.]. Available from: http://www3.ufsm.br/prograd/cursos/ FISIOTERAPIA/CURRICULO/ESTRUTURA CURRICULAR/INTEGRALIZAcaO.pdf

42. Universidade Federal de Santa Maria - UFSM. Centro de Ciências da Saúde. Curso de Fisioterapia. Projeto Político Pedagógico do Curso de Fisioterapia. Santa Maria; [s. d.]. Available from: http://w3.ufsm.br/ prograd/cursos/FISIOTERAPIA/ESTRATeGIAS PEDAGoGICAS.pdf

43. Universidade Federal do Triângulo Mineiro - UFTM. Pró-Reitoria de Ensino. Regulamento das Atividades Acadêmico-Científico-Culturais: Fisioterapia. Uberaba; 2010 [cited 2015 Feb 10]. Available from: http://www.uftm.edu.br/upload/ensino/Regulamento_AACC_Fisioterapia.pdf

44. Universidade Federal de Uberlândia - UFU. Faculdade de Educação Física. Projeto Pedagógico do Curso de Graduação em Fisioterapia. Uberlândia; 2008 [cited 2015 Feb 10]. Available from: http://www.faefi.ufu. br/sites/faefi.ufu.br/files/Anexos/Bookpage/FI_ProjetoPedagogico.pdf

45. Universidade Federal dos Vales do Jequitinhonha e Mucuri - UFVJM. Faculdade de Ciências Biológicas e da Saúde. Projeto Pedagógico do Curso de Graduação em Fisioterapia. Diamantina; 2009 [cited 2015 Feb 10]. Available from: http://www.ufvjm.edu.br/ prograd/index.php?option=com_docman\&task=doc download\&gid=424\&Itemid $=15$

46. Universidade de Brasília - UNB. Faculdade Ceilândia - FCE. Projeto Político Pedagógico do Curso de Fisioterapia. Brasília; [s. d.]. Available from: http:// fce.unb.br/images/PDF/projeto-fisio.PDF

47. Universidade Federal de Alfenas - Unifal. Curso de Fisioterapia: Projeto Político Pedagógico. Alfenas; 2011. Available from: http://www.unifal-mg.edu. br/academico/sites/default/files/Projeto $\% 20$ Pedag\%C3\%B3gico\%20Fisioterapia\%202011.pdf

48. Universidade Federal de São Paulo - Unifesp. Curso de Fisioterapia. Normas das Atividades Complementares de Graduação. Santos; [s. d.]. Available from: http://www.unifesp.br/prograd/ portal/index.php?option=com_docman\&task=doc_ download\&gid=1528\&Itemid=260 
49. Universidade Federal do Pampa - Unipampa. Projeto Pedagógico do Curso de Fisioterapia. Uruguaiana; [s. d.]. Available from: http://cursos.unipampa. edu.br/cursos/fisioterapia/files/2010/09/PPCFISIOTEPAPIA_2011-FINAL1.pdf

50. Brasil. Lei 10.172, de 9 de janeiro de 2001. Aprova o Plano Nacional de Educação e dá outras providências. Brasília; 2001 [cited 2015 Feb 10]. Available at: http://www.planalto.gov.br/ccivil_03/leis/leis_ 2001/l10172.htm

51. Brasil. Ministério da Educação. Parecer CNE/CES n. 492, de 4 de julho de 2001. Institui as diretrizes Curriculares Nacionais dos cursos de Filosofia, História, Geografia, Serviço Social, Comunicação Social, Ciências Sociais, Letras, Biblioteconomia, Arquivologia e Museologia. Brasília; 2001 [cited 2015 Feb 10]. Available from: http://portal.mec.gov.br/cne/arquivos/ pdf/CES0492.pdf

52. Brasil. Lei n. 6.316, de 17 de dezembro de 1975. Cria o Conselho Federal e os Conselhos Regionais de Fisioterapia e Terapia Ocupacional e dá outras providências. Brasília; 1975 [cited 2015 Feb 10]. Available from: http://www.crefito1.org.br/files/6316.pdf

53. Brasil. Ministério da Educação. Resolução CNE/CES n. 4, de 6 de abril de 2009. Dispõe sobre carga horária mínima e procedimentos relativos à integralização e duração dos cursos de graduação em Biomedicina, Ciências Biológicas, Educação Física, Enfermagem, Farmácia, Fisioterapia, Fonoaudiologia, Nutrição e Terapia Ocupacional, bacharelados, na modalidade presencial. Brasília; 2009 [cited 2015 Feb 10]. Available from: http://portal.mec.gov.br/dmdocuments/ rces004_09.pdf
54. Brasil. Lei 13.005, de 25 de junho de 2014. Aprova o Plano Nacional de Educação - PNE e dá outras providências. Brasília; 2014 [cited 2015 Feb 10]. Available from: http://www2.camara.leg.br/legin/fed/ lei/2014/lei-13005-25-junho-2014-778970-publicacaooriginal-144468-pl.html

55. Universidade de São Paulo - USP. Conselho de Graduação e Conselho de Cultura e Extensão. Resolução 4738, de 22 de fevereiro de 2000. Institui a disciplina optativa "Atividades de Cultura e Extensão", nos currículos dos cursos de graduação da USP. São Paulo; 2000 [cited 2015 Feb 10]. Available from: http:// www.leginf.usp.br/?resolucao=resolucao-cog-e-cocex-no-4738-de-22-de-fevereiro-de-2000

56. Brasil. Constituição da República Federativa do Brasil. Brasília; 1988.

57. Moita FMGSC, Andrade FCB. Ensino-pesquisa-extensão: um exercício de indissociabilidade na pós-graduação. Rev Bras Educ. 2009;14(41):269-80.

58. Severino AJ. Educação e universidade: conhecimento e construção da cidadania. Interface (Botucatu). 2002; 6(10):117-24.
Received: 03/12/2014

Recebido: $12 / 03 / 2014$

Approved: 10/09/2014

Aprovado: 09/10/2014 